Jurnal Inovatif Ilmu Pendidikan Vol. 1 No. 1, (2019), HIm. 59-73

http://jurnal.fkip.unila.ac.id/index.php/JIIP/index

JURNAL INOVATIF ILMU PENDIDIKAN

Email : inovatif.ip@fkip.unila.ac.id

\title{
Hubungan Keterlibatan Ayah dalam Pengasuhan Anak dengan Kemandirian
}

\author{
Desy Ayuningrum \\ Perguruan Tinggi Ilmu Alqur`an (PTIQ Jakarta) \\ Jalan Batan I No. 2 Lebak Bulus Cilandak Jakarta Selatan 12440 \\ E-mail: desyayuningrum14@gmail.com
}

\begin{abstract}
Article Info
Received December 2018

Accepted Februari 2019

Published April 2019

Keywords:

Father's involvement, independence,

early childhood

Abstract

The purpose of this study was to determine the relationship of involvement of fathers in parenting with children's independence in Madrasah Ibtidaiyah Pembangunan UIN Jakarta. The independent variable in this study is the involvement of fathers in parenting, and the dependent variable is the independence of children. Data retrieval is done using the scale of father involvement in child care and the independence scale is based on a Likert scale. In this study validity test using Pearson Product Moment Correlation formula and reliability test using Cronbach Alpha with SPSS 22.0 computer program. Based on the results of data analysis, the correlation coefficient between father involvement in parenting and the independence of children was 0.579 with p0,000 <0.05. conclusions obtained are Ho rejected and $\mathrm{Ha}$ accepted. This shows that there is a significant relationship between the involvement of fathers in the care of children and the independence of children in Ibtidaiyah Pembangunan UIN Jakarta in a positive direction. This means that the higher the involvement of the father in caring for the child, the better the child's independence.
\end{abstract}

\begin{abstract}
Abstrak : Tujuan penelitian ini adalah untuk mengetahui hubungan keterlibatan ayah dalam pengasuhan anak dengan kemandirian anak di Madrasah Ibtidaiyah Pembangunan UIN Jakarta. Variabel bebas pada penelitian ini adalah keterlibatan ayah dalam pengasuhan anak, dan variabel terikat adalah kemandirian anak. Pengambilan data dilakukan dengan menggunakan skala keterlibatan ayah dalam pengasuhan anak dan skala kemandirian dibuat berdasarkan skala Likert. Pada penelitian ini uji validitas menggunakan rumus Korelasi Product Moment Pearson dan uji reliabilitas menggunakan Alpha Cronbach dengan program komputer SPSS 22,0. Berdasarkan hasil analisis data diperoleh koefisien korelasi antara keterlibatan ayah dalam pengasuhan anak dengan kemandirian anak sebesar 0,579 dengan p0.000<0,05. kesimpulan yang diperoleh adalah Ho ditolak dan Ha diterima. Hal tersebut menunjukkan adanya hubungan yang signifikan antara keterlibatan ayah dalam pengasuhan anak dengan kemandirian anak di Madrasah Ibtidaiyah Pembangunan UIN Jakarta dengan arah yang positif. Hal ini berarti semakin tinggi keterlibatan ayah dalam pengasuhan anak maka semakin baik kemandirian anak. Kata Kunci : Keterlibatan ayah, kemandirian, anak usia dini
\end{abstract}




\section{PENDAHULUAN}

Pendidikan anak merupakan hal yang sangat penting dalam kehidupan keluarga, untuk itu orang tua memegang peranan penting dalam pendidikan anak. Keberhasilan pendidikan anak biasanya dipengaruhi oleh kepribadian orang tua, disamping pengaruh lingkungan dan sekolah. Sejak lahir kita dihadapkan pada tugas menjadi individu, yaitu mampu berfungsi secara mandiri dan efektif sebagai pribadi yang dewasa. Untuk bisa menjadi manusia dewasa yang sesungguhnya, kita harus melalui sejumlah tahap perkembangan. Tiap-tiap tahap terkait dengan meningkatnya keterpisahan dengan seseorang yang dibarengi dengan menurunnya ketergantungan emosional dan fisik terhadap orangtua.

Kemandirian harus dimiliki setiap individu, kita tidak bisa bergantung terusmenerus kepada orang lain karena dapat menimbulkan dampak kurang baik bagi perkembangan psikologis. Di tengah berbagai tuntutan perubahan yang terus terjadi sekarang ini, banyak individu yang mengalami kekecewaan, frustrasi, dan kehilangan pendirian karena tidak kunjung memperoleh apa yang dinamakan kemandirian.

Menurut Havighurst salah satu tugas perkembangan kanak-kanak adalah mencapai kemandirian pribadi (Hurlock, 1995). Individu yang sudah memiliki sikap hidup mandiri biasanya waktu kecil sudah terbiasa dengan tugas-tugas yang diselesaikan tanpa bantuan. Tentu saja tugas-tugas itu disesuaikan dengan usia dan kemampuannya. Mengingat kemandirian akan banyak memberikan dampak positif bagi perkembangan individu, sebaiknya dilatih sejak dini. Biasanya segala hal yang dibiasakan sejak dini akan lebih mudah dihayati dan akan semakin berkembang menuju kesempurnaan.

Banyak usaha yang dapat dilakukan untuk mendidik dan menumbuhkan kemandirian pada individu. Hal yang terpenting adalah bagaimana orangtua, sebagai orang yang paling mampu mempengaruhi anak, mampu mendukung perilaku mandiri anak. Kemandirian merupakan suatu pola kepribadian yang sifatnya bukan pembawaan melainkan hasil dari proses pembentukan dan pembelajaran. Oleh karena itu kemandirian sudah harus ditanamkan sejak anak masih kecil, agar kelak menjadi individu yang mandiri yaitu individu yang tidak tergantung pada orang lain.

Pada saat ini, di Indonesia banyak orang tua yang sibuk bekerja di luar rumah, baik ayah maupun ibu, sehingga waktu untuk bertemu dan berkomunikasi dengan anak 
sangat terbatas. Meskipun di rumah ada pembantu yang siap membantu sang anak, namun dilihat dari cara mereka memperlakukan majikan kecilnya tidak terlihat ada pembelajaran anak agar sang anak menjadi mandiri. Waktu interaksi antara orangtua dan anak yang terbatas juga merupakan faktor penghalang untuk melatih anak menjadi mandiri. Walaupun di rumah orangtua telah memberikan aturan-aturan yang harus dipatuhi anak, itu juga belum bisa dijadikan acuan bahwa anak dapat mandiri, karena dalam menjalankan aturan yang dibuat, harus ada kerjasama, kekonsistenan serta kedisiplinan dari orangtua dan anak agar aturan tersebut benar-benar berjalan.

Dalam keluarga, biasanya yang bekerja di luar rumah adalah ayah, ayah adalah pencari nafkah utama keluarga dan anak-anak dapat menerima pandangan itu. Karena ibu yang berada dirumah, maka secara otomatis ibulah yang paling sering berinteraksi dengan anak. Ibu yang melihat perkembangan dan pertumbuhan anak-anaknya dari hari ke hari, mengurus anak-anaknya dari anak bangun tidur hingga tiba waktunya untuk tidur kembali. Disini ibu memiliki porsi yang lebih besar dari ayah dalam hal mendidik anak, salah satunya adalah mendidik anak untuk mandiri, seperti mengajarkan anak merapihkan kamarnya sendiri, mengajarkan anak untuk dapat mempersiapkan dirinya ke sekolah dan sebagainya. Dan hal inilah yang peneliti lihat dalam kehidupan sehari-hari, sehingga bisa peneliti katakan bahwa urusan anak adalah urusan ibu.

Pengasuhan anak tidak dapat dilepaskan dari kedua orangtuanya, oleh karena itu tidak ada istilah dominasi dalam pengasuhan anak. Kedua orangtua dengan sisi positif masing-masing akan memberikan pengalaman kepada anak sehingga ada aspek-aspek yang berbeda pada diri anak yang berkembang. Seperti yang dikatakan oleh Nielsen (dalam Immanuella, 2005) bahwa kedekatan yang dijalin ayah dengan anak perempuannya, menghasilkan rasa percaya diri yang kuat pada anak

Karakteristik ayah dan ibu yang berbeda, juga mempengaruhi cara mereka memperlakukan anak. Jika ibu lebih banyak menstimulasi anak dengan lembut, ayah lebih senang menstimulasi buah hatinya dengan permainan yang sedikit "kasar". Perbedaan ini tentu memperkaya batin anak. Dalam bermain misalnya, ayah punya inisiatif lebih tinggi untuk melakukan permainan-permainan yang lebih menantang dan penuh eksperimen, seperti bermain bola bersama ayah dan bermain panjatpanjatan di dinding taman. Biasanya ayah melatih kompetisi yang mengasah 
kemampuan mental dan fisik anak untuk belajar mengeksplorasi dunia dan mengenal kemampuan tubuhnya. Interaksi ayah dan anak sejak dini melalui berbagai permainan bersama terbukti meningkatkan kemampuan kognitif anak, seringnya ayah dan anak bermain bersama, maka anak belajar cara-cara menyelesaikan masalah, berkompetisi dan wawasan berpikirnya terbuka luas. Bahkan anak-anak yang merasa asyik bermain bersama ayahnya biasanya lebih mudah bersosialisasi dan lebih berani, terutama dalam mengemukakan pendapat (Grahita, 2005).

Dari hasil observasi dan wawancara di Madrasah Pembangunan, peneliti melihat kurangnya kerjasama dalam pengasuhan anak terhadap siswa di lingkungan sekolah, hal ini terlihat ketika sekolah mengadakan rapat wali murid, rapat yang sengaja diadakan pada hari sabtu ketika orangtua sedang tidak bekerja, ternyata yang banyak hadir adalah ibu. Contoh lain, pada saat pengambilan rapot yang datang pun lebih banyak ibu.

Sejak tahun 1970-an, banyak ahli psikologi secara langsung meneliti peran ayah dalam keluarga. Seperti penelitian yang dilakukan oleh Blanchard dan Biller (dalam Dagun, 2002) yang mencoba membandingkan empat kelompok anak dalam kemampuan akademiknya. Data diambil dari hasil ujian yang diberikan guru mereka di sekolah. Kelompok pertama adalah anak yang ditinggalkan oleh ayahnya sebelum usia lima tahun, kelompok kedua anak yang ditinggalkan ayahnya setelah usia lima tahun, kelompok ketiga anak yang tidak dekat dengan ayahnya, kurang dari enam jam perminggu, dan kelompok keempat dimana ayah terlibat penuh. Kesimpulan dari penelitian tersebut adalah, anak yang ditinggalkan ayahnya sebelum usia lima tahun tampak bahwa kemampuan akademiknya menurun dibandingkan dengan anak yang ayahnya terlibat penuh dalam proses pembinaan perkembangan anak. Sementara bagi ayah yang hidup bersama anak tetapi kurang terlibat dalam pembinaan anak, kehadirannya hampir tidak banyak dampaknya, bahkan nasib anaknya bisa dibilang sama dengan anak yang ditinggalkan oleh ayahnya. Pengertian absennya seorang ayah pada diri anak bisa karena meninggal, perceraian, atau karena tidak terlibat dalam proses pembinaan langsung perkembangan anak.

Karena itu peneliti tertarik untuk menelitinya, khususnya mengenai keterlibatan ayah dalam pengasuhan anak hubungannya dengan kemandirian anak. Bagaimana keterlibatan ayah dan ibu dalam mengasuh anak, khususnya ayah yang 
kesehariannya berada di luar rumah. Apakah keterlibatan yang tinggi menghasilkan anak yang memiliki keterampilan dan pengembangan diri yang bagus, dalam hal ini adalah kemandirian. Sebaliknya apakah absennya seorang ayah, dalam hal ini ayah tidak terlibat langsung dalam proses perkembangan anak sehingga proses pengasuhan anak menjadi pincang, akan menghasilkan anak yang tidak mandiri.

\section{Kemandirian}

Menurut Mohammad Ali, M..\& Asrori (2004), kata kemandirian berasal dari kata dasar "diri", yang mendapatkan awalan ke dan akhiran an, yang kemudian membentuk suatu keadaan atau kata benda. Karena kemandirian berasal dari kata dasar diri, pembahasan mengenai kemandirian tidak dapat dilepaskan dari pembahasan mengenai pengembangan diri itu sendiri. Kemandirian merupakan aspek yang berkembang dalam diri setiap individu. Kemandirian tidak dapat dibentuk begitu saja, tetapi melalui proses yang panjang. Secara umum proses pembentukan dan perkembangan pribadi mandiri sangat dipengaruhi oleh lingkungan sekitar individu, baik lingkungan keluarga, sekolah dan masyarakat.

Kemandirian menurut Gilmore (dalam Mudjijo, 1993) adalah bersikap dan berlaku mandiri sebagai kebebasan seseorang dari pengaruh dan pengawasan orang lain. Hal ini menunjukkan bahwa orang yang memiliki kemandirian mempunyai kemampuan untuk menentukan sendiri apa yang harus dilakukan, dapat mengambil keputusan sendiri dalam memilih kemungkinan-kemungkinan dan memecahkan sendiri problem yang dihadapi tanpa mengharapkan bantuan dari orang lain.

Martin dan Stendler (dalam Afiatin, 1993) mengemukakan bahwa kemandirian ditunjukkan dengan kemampuan seseorang untuk berdiri di atas kaki sendiri, mengurus diri sendiri dalam semua aspek kehidupannya, ditandai dengan adanya inisiatif, kepercayaan diri dan kemampuan mempertahankan diri dan hak miliknya. Sedangkan menurut Brawer (dalam Supartinah \& Sugiyanto, 1992) kemandirian merupakan perilaku yang terdapat pada seseorang yang timbul karena dorongan dari dalam diri sendiri, bukan karena pengaruh dari orang lain. Dengan kemandirian seseorang mampu menunjukkan kontrol diri dalam perilakunya.

Selanjutnya kemandirian menurut Barnadib (dalam Mu'tadin, 2002) meliputi perilaku mampu berinisiatif, mampu mengatasi hambatan atau masalah, mempunyai rasa percaya diri dan dapat melakukan sesuatu sendiri tanpa bantuan orang lain. 
Pendapat tersebut juga diperkuat oleh Kartini dan Dali (dalam Mu'tadin, 2002) yang mengatakan bahwa kemandirian adalah hasrat untuk mengerjakan segala sesuatu bagi diri sendiri.

Dari uraian diatas maka dapat penulis simpulkan bahwa kemandirian merupakan kemampuan untuk melakukan sesuatu tanpa bantuan orang lain khususnya orangtua, mencoba mengatasi masalahnya sendiri, memiliki kepercayaan diri dalam melaksanakan tugas-tugasnya dan mengarahkannya menuju kesempurnaan.

\section{Ciri-ciri Kemandirian}

Secara lebih rinci Beller (dalam Afiatin, 1993) menyebutkan beberapa tanda kemandirian yaitu : pengambilan inisiatif, mencoba mengatasi rintangan-rintangan dalam lingkungan, mencoba mengarahkan tingkah lakunya menuju kesempurnaan, memperoleh kepuasan dari bekerja dan mencoba mengerjakan tugas rutinnya.

Tanda-tanda kemandirian lain dikemukakan oleh Smart dan Smart (dalam Afiatin, 1993) yaitu: adanya kepercayaan diri, mempunyai tujuan dan kontrol diri, mampu dan puas atas pekerjaannya dan bersifat eksploratif.

Medinus, dkk (dalam Supartinah\&Sugiyanto, 1992) mengemukakan ciri-ciri orang yang mandiri, yaitu : (1) mampu mengambil inisiatif, (2) senang mencoba mengatasi tugas dalam lingkungannnya, (3) melakukan aktivitas untuk mencari penyelesaian masalah, (4) merasa puas dari hasil usahanya sendiri, (5) mampu berusaha mendewasakan diri, dan (6) lebih tertarik kepada ide-ide yang asli daripada aspek-aspek praktis dalam persoalan.

Frank dkk (1988) mengukur kemandirian berdasarkan lima aspek kemandirian yang dijadikan sebagai kerangka penelitian, yaitu:

1. Pengambilan keputusan

Mampu mengambil keputusan dan pilihan-pilihan yang sesuai dengan tujuan hidup, nilai yang dianut serta minat, dan tidak ikut serta malu bila keputusan yang diambil berbeda dengan pilihan atau keyakinan orang lain.

2. Kontrol diri

Adanya kontrol pribadi dalam berhubungan dengan orang lain, bebas dari rasa cemas atau takut dan tidak tergantung kepada orang lain. 


\section{Sikap asertif}

Mampu menilai diri sendiri dan mampu mengungkapkan nilai atau kebutuhan yang mungkin bertentangan dengan orang lain.

4. Kebebasan

Mampu memecahkan masalah tanpa mengharapkan bantuan orang lain dalam melaksanakan tugas, tidak mengalami kesulitan bila menghadapi tantangan serta tidak mendapat bantuan dari orang lain.

5. Tanggung jawab terhadap diri sendiri dan orang lain

Bertindak sesuai norma dan menyadari hak dalam masyarakat.

Dari uraian yang telah dikemukakan di atas, jelas bahwa setiap aspek menunjukkan karakteristik individual yang berbeda sehingga setiap individu sebagai kesatuan jasmani dan rohani mewujudkan dirinya secara utuh dalam keunikannya. Keunikan dari perbedaan individual ini diperoleh dari perbedaan pembawaan dan lingkungan yang dimiliki oleh masing-masing individu.

\section{Tahap-tahap Pengembangan Kemandirian Anak}

Parker (2006) mengemukakan tahap-tahap pengembangan kemandirian sebagai berikut:

1. Tahap pertama

Mengatur kehidupan dan diri mereka sendiri: misalnya, makan, ke kamar mandi, mencuci, membersihkan gigi, memakai pakaian. Ketika anak mulai sekolah, mereka mesti membersihkan tempat tidur dan memakai pakaiannya sendiri.

2. Tahap kedua

Melaksanakan gagasan-gagasan mereka sendiri dan menentukan arah permainan mereka sendiri. Dalam tahap ini anak melakukan ide dan gagasan yang mereka miliki, anak memiliki inisiatif untuk melakukan suatu pekerjaan dan berusaha menyelesaikannya, seperti belajar dan mengerjakan PR (pekerjaan rumah) tanpa menunggu perintah dari orang tua.

3. Tahap ketiga

Mengurus hal-hal di dalam rumah dan bertanggung jawab terhadap: 
- Sejumlah pekerjaan rumah tangga: misalnya, menjaga kamarnya tetap rapi, mencuci peralatan makannya seusai makan.

- Mengatur bagaimana menyenangkan dan menghibur dirinya sendiri dalam alur yang diperkenankan. Seperti menulis cerita, mendengarkan musik, membaca buku dan sebagainya.

- Mengelola uang saku mereka sendiri.

Pada masa ini, anak-anak harus diberi kesempatan untuk terlibat dalam pengambilan keputusan yang mempengaruhi kehidupan mereka, misalnya, kegiatan ekstra yang akan anak ikuti, kesepakatan adanya hadiah tertentu yang diberikan karena tanggung jawab dan komitmen tambahan.

4. Tahap keempat

Mengatur diri mereka sendiri di luar rumah, menyiapkan segala keperluannya, kehidupan sosial mereka, klub, aktivitas ekstra dan lain sebagainya.

5. Tahap kelima

Mengurus orang lain baik di dalam maupun di luar rumah, misalnya menjaga adik ketika orang tua sedang mengerjakan sesuatu yang lain.

Ada beberapa faktor yang mempengaruhi perkembangan kemandirian antara lain: 1) Kebudayaan; 2) Pola asuh orangtua; 3)Usia; 4) Jumlah anak dalam keluarga; 5) Intelegensi; 6) Jenis kelamin; 7) Gen atau keturunan orang tua; 8) Sistem pendidikan di sekolah; 9) Sistem kehidupan masyarakat

\section{Ciri Utama Peran Ayah}

Hasil wawancara Shapiro (2003) dengan lebih dari delapan ratus ayah dan anak-anak yang sudah dewasa, memberikan dua belas ciri utama yang terkait dengan peran ayah; 1) Melindungi dan Memberi Nafkah; 2) Mencintai dan Melibatkan Diri dengan Anak-anak; 3) Menghadapi Rasa Takut Gagal; 4) Memberi Semangat dan Dukungan; 5) Menjadi Pemberan; 6) Bisa Dipercaya; 7) Menghormati Perasaan dan Kehangatan Pria; 8) Bersikap Fleksibel; 9) Menegakkan Disiplin; 10) Mencontohkan dan Mengajarkan Kerja Sama Kelompok; 11) Memahami dan Menghormati Keterbatasan Pribadi;n 12) Menerima Diri Anda dan Peran Anda sebagai Ayah. 


\section{Pengertian Keterlibatan Ayah dalam Pengasuhan Anak}

Keterlibatan dalam pengasuhan anak mengandung aspek waktu, interaksi, dan perhatian. Lamb (dalam Andayani \& Koentjoro, 2004) dalam menganalisis keterlibatan ayah mengkategorikan keterlibatan dalam tiga bentuk. Engagement atau interaction adalah interaksi satu-dengan-satu dengan anak, meliputi kegiatan seperti memberi makan, bermain, berbincang, mengerjakan PR, dan sebagainya. Accessibility adalah bentuk keterlibatan yang lebih rendah. Orangtua ada di dekat anak tetapi tidak berinteraksi secara langsung dengan anak. Responsibility adalah bentuk keterlibatan yang paling intens karena melibatkan perencanaan, pengambilan keputusan, dan mengorganisasi.

Budi Andayani dan Koentjoro mengemukakan aspek-aspek keterlibatan ayah dalam pengasuhan anak yang dirangkum dari teori Grant dan Benn\&Garbarino yang selanjutnya akan digunakan sebagai kerangka penelitian, yaitu:

1. Frekuensi

Ayah yang terlibat dalam pengasuhan anak adalah ayah yang berpartisipasi aktif terus menerus dalam pengasuhan anak. Pengasuhan anak bukanlah suatu kegiatan yang selesai dalam sehari, melainkan berkesinambungan dari waktu ke waktu dan dari suatu tahap perkembangan ke tahap perkembangan berikutnya. Dengan pengertian berulang (frequent) berarti partisipasi seorang ayah, sebagaimana ibu, terjadi dalam frekuensi yang lebih dari sekedar sekali dalam satu kurun waktu yang panjang (Andayani \& Koentjoro, 2004).

2. Inisiatif

Seorang ayah dikatakan terlibat dalam pengasuhan anak ketika ayah berinisiatif untuk menjalin hubungan dengan anak dan memanfaatkan semua sumber dayanya baik fisik, kognisi dan afeksinya. Seorang ayah terlibat dalam interaksi dengan anak sebagai seorang ayah, bukan layaknya seorang baby sitter yang menggantikan ibu sementara ibu sedang tidak dapat meninggalkan pekerjaan yang lain. inisiatif juga dibutuhkan karena dalam mengasuh anak ada situasi-situasi sulit dan seorang ayah harus berusaha sendiri mencari cara untuk mengatasi situasi sulit tersebut (Budi Andayani \& Koentjoro, 2004). 


\section{Afeksi}

Ketika seorang ayah memanfaatkan sisi emosionalitasnya ia akan terlibat dengan hangat ketika berinteraksi dengan anaknya. Seorang ayah dapat memanfaatkan afeksinya sebagai landasan berinteraksi dengan anak (Andayani \& Koentjoro, 2004).

4. Fisik

Seorang ayah yang terlibat dalam pengasuhan anak akan melakukan kontakkontak fisik dengan anaknya, baik dalam bentuk sentuhan, ataupun dalam permainan (Andayani \& Koentjoro, 2004).

5. Kognisi

Adanya waktu yang terfokus pada anak atau focused time ketika bersama anak. Perhatian diberikan pada anak saat orang tua bersama mereka, bukan secara fisik bersama tetapi pikiran orang tua terpecah pada hal lain. dengan waktu yang terfokus ini ayah dapat menggunakan semua proses kognisinya untuk menjalin hubungan yang akrab dengan anak. Ayah dapat saja mengembangkan gagasangagasan dalam berinteraksi sambil pada saat itu tetap menyadari apa yang menjadi kebutuhan anak sehingga terbentuk pengertian dan penerimaan. (Andayani \& Koentjoro, 2004)

\section{Keterkaitan antara Keterlibatan Ayah dalam Pengasuhan Anak dengan Kemandirian}

Dalam kehidupan sehari-hari, keamanan saja belum cukup untuk mengembangkan kepribadian orang dewasa yang sehat. Anak-anak juga perlu kebebasan. Di dalam keluarga tradisional, disinilah seorang ayah bisa berperan. Menurut Shapiro (2003), sebagai wakil keluarga terhadap dunia luar, sosok ayah memberi anak-anak keberanian untuk mulai melakukan interaksi dengan dunia luar. Seorang ayah memberi anak-anaknya kesempatan untuk menguji diri mereka sendiri terhadap standar-standar yang objektif untuk merasakan arti kesuksesan dan kegagalan akibat persaingan dengan orang lain, sekaligus belajar tentang pilihan-pilihan yang tidak mereka jumpai dalam keluarga. Selain itu, ayah dapat membantu anak-anaknya menjadi individu yang mandiri dengan memberi contoh sekaligus menjadi agen sosialisasi. Dalam keluarga, ayah merupakan sosok utama yang terikat, sekaligus memiliki otonomi, karena ayah tidak memiliki hubungan fisik-emosi yang simbiosis. 
Adanya dua model peran, yaitu model yang terikat dan model yang mandiri dalam keluarga, akan membantu sang anak belajar mengembangkan kejiwaan internal sebagai individu yang mandiri dan memungkinkan anak untuk mengenali dirinya sebagai individu (Shapiro, 2003).

Stephen Shapiro (Shapiro, 2003) mengatakan, "Tindakan seorang ayah adalah upaya seimbang antara memberikan dukungan dan waspada terhadap bentuk ketergantungan yang sifatnya kekanak-kanakan." Sebagai sosok yang secara fisik dan emosi menjadi wakil keluarga terhadap dunia luar, seorang ayah dapat membantu anak-anaknya beradaptasi dari realitas rumah ke dalam realitas budaya dan masyarakat tempat mereka dilahirkan. Dengan ayah, anak-anak dapat melatih tingkah laku yang memicu rasa percaya diri dalam menghadapi dirinya sendiri, melatih keterampilan, melaksanakan tugas-tugasnya baik di rumah maupun di luar rumah serta belajar mandiri.

\section{METODE}

Penelitian ini menggunakan pendekatan kuantitatif asosiatif dengan teknik korelasional yaitu untuk mengetahui hubungan variabel independent terhadap variabel dependent. Variabel bebas pada penelitian ini adalah keterlibatan ayah dalam pengasuhan anak, dan variabel terikat adalah kemandirian anak. Populasi yang digunakan adalah anak yang duduk di bangku kelas enam ibtidaiyah (SD) Madrasah Pembangunan UIN Jakarta dengan jumlah 308 orang, jumlah sampel uji coba 30 orang dan sampel penelitian berdasarkan Nomogram Harry King sebanyak 132 orang dengan menggunakan teknik Purposive Random Sampling.

Teknik pengumpulan data dilakukan dengan menggunakan skala keterlibatan ayah dalam pengasuhan anak dan skala kemandirian dibuat berdasarkan skala Likert. Aitem-aitem dalam skala ini merupakan pernyataan dengan empat pilihan jawaban, yaitu SS (Sangat Setuju), S (Setuju), TS (Tidak Setuju), STS (Sangat Tidak Setuju). Skala disajikan dalam bentuk pernyataan favorabel dan tidak favorabel. Bobot penilaian untuk pernyataan favorabel yaitu: $\mathrm{SS}=4, \mathrm{~S}=3, \mathrm{TS}=2$, $\mathrm{STS}=1$, sedangkan bobot penilaian untuk pernyataan tidak favorabel yaitu: $\mathrm{SS}=1, \mathrm{~S}=2, \mathrm{TS}=3$, STS $=$ 4. 
Metode analisis data yang akan digunakan untuk pengujian hipotesis dalam penelitian ini adalah dengan menggunakan statistik analisa korelasi pearson product moment dengan bantuan SPSS versi 22 for windows. Sebelum dilakukan analisa data terlebih dahulu dilakukan uji asumsi terhadap hasil penelitian yang meliputi uji normalitas dengan menggunakan Kolmo- gorov-Smirnov dan uji linieritas menggunakan uji F (test for linearity) atau Analisa Varians (ANAVA).

\section{HASIL DAN PEMBAHASAN}

Sebelum angket diberikan kepada sampel, angket tersebut ditryoutkan/diujicobakan terlebih dahulu kepada 30 siswa di luar sampel. Item angket dinyatakan valid jika $r$ xy $>r$ tabel pada taraf signifikansi $(\alpha)=5 \%$ yaitu 0,374 dan sebaliknya. Dari uji validitas angket keterlibatan ayah dalam pengasuhan anak (40 soal) dan angket kemandirian siswa (36 soal) item soal untuk angket keterlibatan ayah dalam pengasuhan anak 33 item dinyatakan valid, sedangkan untuk angket kemandirian belajar 32 item dinyatakan valid. Angket dikatakan reliabel jika $r$ hitung $>$ rtabel dan nilai $r$ positif. Hasil uji reliabilitas angket minat belajar dan kedisiplinan belajar memperoleh koefisien reliabilitas ( $\mathrm{r}_{11}$ ) masing-masing sebesar 0,942 dan 0,944. nilai ( $\left.\mathrm{r}_{11}\right)$ dari masing-masing variabel lebih besar dari rabel pada taraf signifikansi $(\alpha)=5 \%$ yaitu sebesar 0,444 sehingga angket dinyatakan reliabel dan layak digunakan sebagai instrumen penelitian.

Berdasarkan hasil uji prasyarat analisis pertama yaitu uji normalitas yang berguna untuk mengetahui data dari sampel penelitian berasal dari populasi yang berdistribusi normal. Uji normalitas menggunakan uji liliefors melalui uji KolmogorovSmirnov dalam program SPSS For Windows versi 22.. didapatai hasil sebesar 0,000 ( $<$ < 0.05) sehingga data dari keterlibatan ayah dalam pengasuhan anak dan kemandirian anak di Madrasah Ibtidaiyah Pembangunan UIN Jakarta berdistribusi normal. berdistribusi normal.

Analisis korelasi dilakukan untuk mengetahui hubungan atau korelasi antara keterlibatan ayah dalam pengasuhan anak dengan kemandirian anak. SPSS For Windows versi 22.0 diperoleh hasil 0, 579 dengan nilai signifikansi 0,000 atau $\mathrm{p}<0,05$. Hasil ini menyatakan bahwa jika ada hubungan antara pengasuhan anak dengan kemandirian anak. 


\section{Pembahasan}

Berdasarkan hasil analisis data dengan menggunakan program SPSS versi 13,0 for windows didapatkan koefisien korelasi sebesar 0,579 dengan p sebesar 0.000 $(\mathrm{p}<0.05)$. Dari hasil ini menunjukkan adanya hubungan yang signifikan antara keterlibatan ayah dalam pengasuhan anak dengan kemandirian anak di Madrasah Ibtidaiyah Pembangunan UIN Jakarta dengan arah korelasi yang positif, sehingga dapat disimpulkan bahwa semakin ayah terlibat dalam pengasuhan anak maka semakin baik kemandirian anak.

Hal ini sesuai dengan pendapat Nielsen, psikolog dari Amerika Serikat, ini karena perbedaan cara asuh ayah dan ibu. Ibu selalu memberi petunjuk pada anak tentang apa saja yang harus dilakukan. Sementara para ayah muncul sebagai sosok yang keras dan penuntut. Dari sikap ayah yang demikian, anak mengembangkan kekuatan, disiplin diri dan kemandirian dengan mengajarkan keyakinan akan kekuatannya sendiri untuk mengendalikan apa yang terjadi pada dirinya sendiri. Para ayah mengajarkan sikap asertif, cara-cara untuk berhasil dalam menghadapi kekuasaan pria dan cara-cara berinteraksi dalam kelompok, serta semua keterampilan yang diperlukan anak dalam menjalani dunia persekolahan dan pekerjaan (dalam Immanuella F. R, 2005 : 61-62).

Para ayah memiliki perbedaan dengan cara sang ibu berinteraksi dengan anak. Ibu umumnya berinteraksi dengan lebih tenang, stabil dan lembut. Ibu akan lebih cenderung memainkan mainan yang sudah lazim seperti cilukba, tepuk tangan, membaca buku, menggerakkan mainan atau puzzle. Dengan ayah, anak akan bermain lompat-lompatan, memanjat, kuda-kudaan atau pesawat terbang dengan mengangkat tubuh anak, permainan-permainan yang melibatkan emosi tinggi dan menggairahkan. Ayah akan menjadi "pelatih emosi" yang berbeda dengan ibu, dengan dua pelatih emosi yang berbeda inilah diharapkan hasil didikan ibu dan ayah akan mencapai keseimbangan dalam pribadi anak.

Selain itu, ayah dapat membantu anak-anaknya menjadi individu yang mandiri dengan memberi contoh sekaligus menjadi agen sosialisasi. Dalam keluarga, ayah merupakan sosok utama yang terikat, sekaligus memiliki otonomi, karena ayah tidak memiliki hubungan fisik-emosi yang simbiosis. Adanya dua model peran, yaitu model yang terikat dan model yang mandiri dalam keluarga, akan membantu sang anak belajar 
mengembangkan kejiwaan internal sebagai individu yang mandiri dan memungkinkan anak untuk mengenali dirinya sebagai individu (dalam Shapiro, 2003).

Berdasarkan perhitungan kategorisasi pada masing-masing variabel, diperoleh Mean dari keterlibatan ayah dalam pengasuhan anak sebesar 125,57 dan Mean dari kemandirian sebesar 121,07 dimana kedua-duanya berada pada kategori tinggi. Hal ini menunjukkan bahwa siswa kelas VI Ibtidaiyah di Madrasah Pembangunan UIN Jakarta memiliki ayah yang mempunyai keterlibatan tinggi dalam hal pengasuhan anak sehingga anak memiliki kemandirian yang baik. Kondisi tersebut dapat terjadi karena adanya kerjasama dalam pengasuhan anak, kemampuan ayah dalam menjalin hubungan yang baik dengan anak maka secara otomatis ayah akan menyadari apa yang dibutuhkankan anak, seperti melatih kontrol diri dalam diri anak, ayah dapat membantu anak menyalurkan kemarahannya menjadi persaingan, kompetensi, dan motivasi yang tepat. Perhatian, kasih sayang, rasa nyaman serta rasa aman yang diberikan ayah dapat melatih tingkah laku yang memicu rasa percaya diri dalam diri anak menghadapi teman sebaya, bertanggung jawab dan tidak bergantung pada orang lain.

\section{KESIMPULAN}

Berdasarkan hasil analisis data penelitian maka diperoleh hasil "Ada hubungan yang signifikan antara keterlibatan ayah dalam pengasuhan anak dengan kemandirian anak di madrasah Ibtidaiyah Pembangunan UIN Jakarta”, dengan arah hubungan yang positif. Hal ini memiliki arti semakin tinggi keterlibatan ayah dalam pengasuhan anak maka semakin baik kemandirian yang dimiliki anak. Hasil korelasi yang tidak terlalu tinggi sebesar 0,579 menunjukkan bahwa selain keterlibatan ayah ada faktor-faktor lain yang mempengaruhi kemandirian antara lain kebudayaan, pola asuh orang tua, usia anak, jumlah anak dalam keluarga, intelegensi pada diri anak, jenis kelamin, gen/keturunan orang tua, sistem pendidikan di sekolah dan sistem kehidupan masyarakat.

Diharapkan pada para ayah untuk dapat mempertahankan keterlibatannya dalam pengasuhan anak. Keterlibatan ayah dalam pengasuhan anak dapat ditempuh antara lain dengan menjalin hubungan yang baik dengan anak; memberikan perhatian, meluangkan waktu bersama anak, menjalin komunikasi aktif dengan anak serta menunjukkan arti kasih sayang seperti memberi rangkulan. 


\section{DAFTAR PUSTAKA}

Afiatin, T. (1993). Persepsi pria dan wanita terhadap kemandirian. Jurnal Psikologi, 20(1993) Hlm. 8-9.

Ali, M..\& Asrori, M.. (2004). Psikologi Remaja Perkembangan Peserta Didik. Jakarta : PT. Bumi Aksara.

Andayani, B \& Koentjoro. (2004). Peran Ayah Menuju Coperanting. Yogyakarta : CV. Citra Media.

Dagun, SM. (2002). Psikologi Keluarga. Jakarta: PT. Rineka Cipta.

Frank, et all. (1988). Young Adults Perception of Their Relationships With Their Parents: Individual Differences in Connectedness, Competence, and Emotional Autonomy. Journal of Development Psychology, 24 (5), 729-737.

Grahita Purbasantika Nugraha. (2005). Aku Suka Ayah Karena.... Ayah bunda. Jakarta : PT. Aspirasi Pemuda.

Hurlock B. Elizabeth. (1995). Perkembangan Anak. Jilid ke-1. Jakarta : Erlangga.

Immanuella, F Rachmani. (2005). Ayahku, Cintaku. Ayah Bunda. Jakarta : PT. Aspirasi Pemuda.

Mu’tadin, Z. (2002). Kemandirian Sebagai Kebutuhan Psikologis Pada Remaja. www.e-psikologi.com. (Di akses 10 Januari 2019).

Mudjijo. (1993). Kemandirian dan Prestasi Hasil Belajar Mahasiswa. Laporan Penelitian, hal 19. Padang : Institut Keguruan dan Ilmu Pendidikan Padang.

Parker, K. Deborah. (2006). Menumbuhkan Kemandirian dan harga Diri Anak. Jakarta : Prestasi Pustaka Ria.

Supartinah, T \& Sugiyanto. (1992). Kontribusi Harga Diri, Kemandirian dan Motif Berprestasi Terhadap Prestasi Akademik Mahasiswa FKIP - UNS Surakarta. Laporan Penelitian, hal 19-21. Surakarta: Universitas Sebelas Maret. 